\title{
Analysis of Customer Satisfaction Factors on e-Commerce Payment System Methods in Indonesia
}

\author{
Hafidz Risqiadi Putra ${ }^{1}$, Sfenrianto ${ }^{2}$ \\ Information System Management Department, BINUS Graduate Program - Master of Information System \\ Bina Nusantara University \\ Jakarta, Indonesia, 11480
}

\begin{abstract}
Commerce companies are currently competing to make it easier for customers to make transactions with a variety of payment system methods that have been provided and developed. The research aims to find out the factors that influence customer satisfaction in using the payment system method. The variables used in the study are service, comfort, speed, convenience, benefits, active use and security in conducting transactions. The results of the study concluded what factors influence satisfaction to develop a payment system method. The research model and questionnaire use a modified research model of the successful information system model DeLone and McLane and technology acceptance by Tella (2012) and in analyzing the results of the questionnaire, researchers used descriptive statistics and Structural Equation Model (SEM) analysis using AMOS V.26. The results of the management of these data the researchers concluded that there is one variable that is perceived comfort does not significantly affect satisfaction. Results of this study are expected to provide a reference that can be used by digital business people, particularly financial technology or e-commerce companies in improving services in applying the Payment System Method by factors that influence the level of customer satisfaction to maintain customer loyalty to the company.
\end{abstract}

Keywords-e-Commerce; payment system methods; DeLone and McLean; Structural Equation Model (SEM)

\section{INTRODUCTION}

The development of information technology in Indonesia currently continues to increase, Indonesia as a developing country must always follow the trends in the use of existing technology. One form of development of digital information technology in Indonesia today is the increase in internet users and the emergence of various types of companies in the field of e-commerce business in Indonesia. Based on the results of the APJI and Polling Indonesia survey the number of internet users in Indonesia in 2018 increased by 27.91 million $(10.12 \%)$ to 171.18 million people from the previous year. This means that internet penetration in Indonesia has increased to $64.8 \%$ of the total population of 264.16 million people. While in the same year, in Fig. 1 the number of e-commerce transactions in Indonesia has reached around 144 trillion Rupiah in Indonesia.

Within the e-Commerce company, there are various payment system methods that can be used by companies to facilitate customers in making transactions, payment systems that are generally applied are online credit cards, e-wallet, digital cash, online stored value systems, transfers online banks, digital accumulating balance systems, digital check payment systems to Cash on Delivery (COD) payment methods. It's just that in practice the implementation is not all types of payment systems that are applied in e-commerce transactions in Indonesia due to applicable legality or payment security systems that are still under construction. Infrastructure in the application of supporting electronic payments is very important to promote e-commerce, which supports the main relationship between e-commerce and the financial foundations of the economy [2].

A high level of customer satisfaction on transactions made online tends to increase customer commitment considering satisfaction is one of the interactive factors [3]. This study aims to analyze the data collected by researchers on customer satisfaction regarding payment system methods that have been applied in e-commerce companies in Indonesia and assist companies in creating customer loyalty to reduce the sensitivity of failures in e-commerce companies in Indonesia and find out factors that can affect customer satisfaction in the Payment System Method that has been applied. The method used by researchers in making this research questionnaire is by modifying the successful model of the DeLone and McLane information system and the technology acceptance model by Tella [4], while analyzing the results of the questionnaire the researcher uses descriptive statistics and modeling using Structural Equation Model (SEM). This research is expected to help in evaluating the factors that support to increase the success of the development of Payment System [5] Methods or to be one of the references in the development [6] of ecommerce companies to startup companies based on Fintech (Financial Technology) in Indonesia.

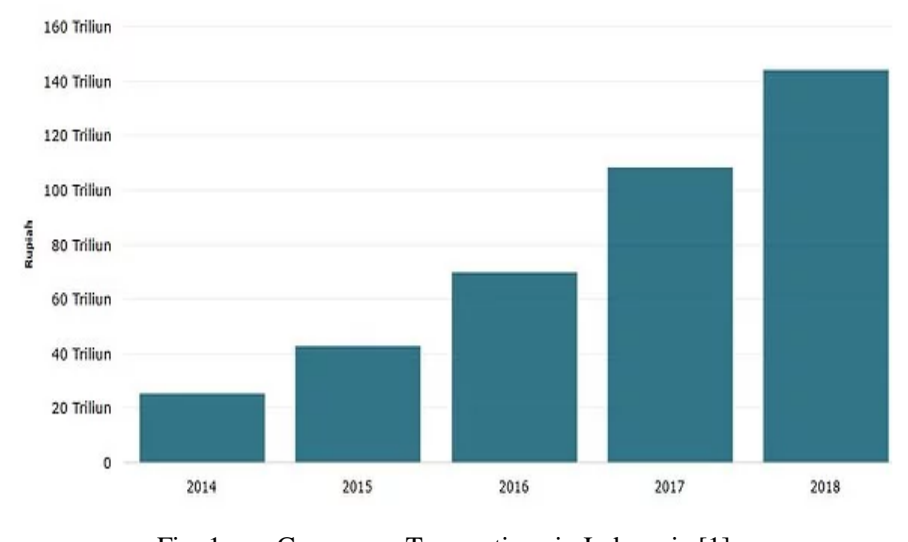

Fig. 1. e-Commerce Transactions in Indonesia [1]. 


\section{A. Research Questions}

In view of the research problem, the study seeks to address the following research questions:

- What factors affect the level of customer satisfaction with the payment system method applied by eCommerce companies in Indonesia?

\section{B. Research Objective}

The research conducted is a study of studies on eCommerce customers, especially in terms of customer satisfaction with payment system methods on e-Commerce in Indonesia. The object of research is customers who have made payment transactions in e-Commerce at least 1 (once). This research was conducted using a questionnaire instrument that was randomly distributed via digital media (softcopy) or manual (hardcopy). Because of the limited research time, the respondents were limited to 425 (Four Hundred Twenty-Five) respondents. This figure is obtained based on the results using the Slovin Technique to determine valid sample sizes in the research conducted.

\section{LITERATURE REVIEW}

\section{A. Electronic Commerce (e-Commerce)}

E-commerce can be classified by identifying the participants involved in the transaction. The following is a general classification of e-commerce based on participation [7], namely:

1. Business to Business (B2B), the Company makes transactions with other companies such as manufacturers selling to distributors and wholesalers selling to retailers.

2. Business to Consumer (B2C), the Company conducts transactions with the general public or consumers directly.

3. Consumer to Customer (C2C), consumers make transactions with other customers.

4. Consumer to Business (C2B), consumers make transactions with companies.

5. Non-business e-commerce, nonbusiness organizations or government agencies that use e-commerce to reduce operating costs and improve public services.

6. Intrabusiness (Organizational), all internal activities of the organization, usually carried out through internet media which involve the exchange of goods, services, and information.

\section{B. Payment System}

Payment system is a system that includes a set of rules, institutions, and mechanisms used to carry out the transfer of funds to meet an obligation arising from an economic activity. Components of the Payment System clearing mechanism until settlement and other components such as institutions involved in administering the payment system. Included in this case are banks, financial institutions other than banks, non-bank institutions that operate funds transfers, switching companies, and even central banks.[8].

\section{Electronic Payment}

According to [9] there are 6 (six) electronic payment systems used in E-commerce,

- Credit Card, a credit card is a payment card issued to users as a payment system. This allows cardholders to pay for goods and services based on cardholders' promises to pay for them.

- Bank Transfers, transfers between bank accounts from merchants can be done by customers both online and offline.

- Electronic Wallets (e-Wallets), an electronic wallet is a wallet that is usually filled with credit card information or refilled via bank transfer. The following are examples of e-Wallets (Kaspay, PayPal, BCA Flazz)

- Cash on Delivery (COD), the consumer pays cash when he receives the goods at home or an agreed place. The transaction manager is carried out by the merchant himself or using a courier.

- Loans, customers ask for loans when checking out. The bank or the borrower will respond in some time with the approval or rejection of customer requests. If the request has been approved, the customer prints,

- Joint Account, This joint account involves a third party that aims to hold funds until the transaction is completed and the goods arrive from the seller's hands to the buyer as a whole. When the goods arrive, the buyer is required to confirm that the funds are released to the seller immediately.

D. Modification of the Success Model of DeLone and McLean Information Systems by Tella (2012)

A high level of customer satisfaction [10] on transactions made online tends to increase customer commitment considering satisfaction [3] is one of the interactive factors. This study aims to analyze the data collected by researchers on customer satisfaction regarding payment system methods that have been applied in e-Commerce companies in Indonesia and assist companies in creating customer loyalty to reduce the sensitivity of failures in e-Commerce companies in Indonesia and find out factors that can affect customer satisfaction in the Payment System Method that has been applied. In Fig. 2, method used by researchers in making this research questionnaire is by modifying the successful model of the DeLone and McLane information system and the technology acceptance model by Tella [4], while analyzing the results of the questionnaire the researcher uses descriptive statistics and modeling using Structural Equation Model (SEM). This research is expected to help in evaluating the factors that support to increase the success of the development of Payment System Methods [11] or to be one of the references in the development of e-Commerce companies to startup companies based on Fintech (Financial Technology) in Indonesia. 


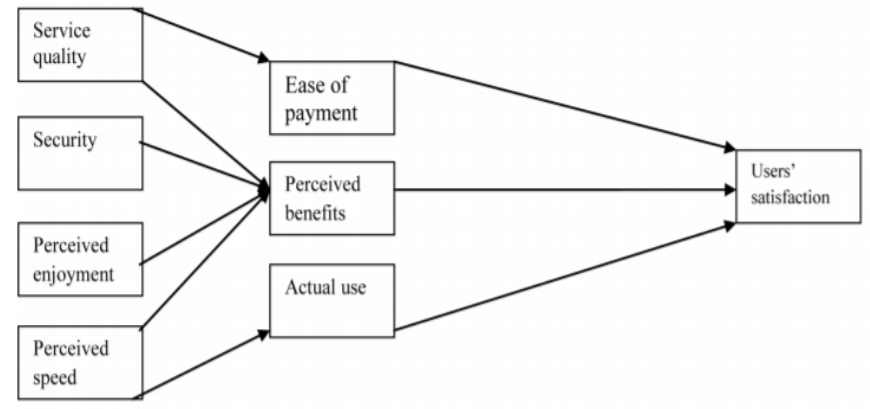

Fig. 2. Success Models for e-Payment Systems [1].

\section{E. Structural Equation Modeling (SEM)}

Structural Equation Modeling (SEM) is a multivariate analysis technique developed to cover the limitations of previous analysis models that have been used extensively in a study. Structural Equation Modeling is a multivariate analysis that can analyze complex variable relationships. This technique allows researchers to examine the relationship between latent variables with manifest variables (measurement equations), the relationship between one latent variable with another latent variable (structural equations), as well as describing measurement errors. Latent variables are variables that cannot be measured directly and require several indicators as proxies, while manifest variables are indicators used in these measurements[12].

In this study Structural Equation Modeling (SEM) analysis techniques using IBM SPSS AMOS V.26, tools are used to analyze the relationship between independent variables namely service quality, ease of payment, speed and enjoyment/pleasure obtained, security, real use, and perceived benefits the dependent variable is user satisfaction when transacting through e-Commerce with one of the payment methods that has been applied in Indonesia.

\section{MethodologY}

\section{A. Research Design}

This study begins by explaining the general picture of the research to be carried out, afterward knowing the problem of the research object to be examined from the general description of the research, namely knowing the level of customer satisfaction[13] with the Payment System Method that has been applied by e-commerce companies in Indonesia and its influence. After knowing or identifying the problem, a literature study is carried out to look for theories that support research and can be used as a reference for starting research, as well as looking for journals or related articles related to this research topic. Followed by making a questioner by using a modification of the successful model of the DeLone and McLane information system and the technology acceptance model by Tella [4], after which a random questionnaire is distributed to e-Commerce customers who have made online transactions. Data collected in Analysis with descriptive statistics as infographics of data collected and analyzed by modeling using Structural Equation Model (SEM) to determine the factors that influence customer satisfaction with Payment System Method which has been applied by e-Commerce in
Indonesia, After the analysis is carried out, the researcher will write the results that can be drawn conclusions in the study and write suggestions as a reference both in further research or as a reference for the development of the Payment System Method in Indonesia.

\section{B. Determine Sample}

Based on data obtained based on survey results published by the Indonesian Internet Service Providers Association [14] as in Fig. 3, there are a total of 143.26 million users who use the internet. $29.55 \%$ of users or equivalent with $42,333,330$ users aged 35-54 years, while for ages 54 and over there are $4.24 \%$ of total internet users or equivalent to $6,074,224$ users. From the total population, the data taken from the sample can describe the actual population which is by the provisions in credit card ownership to obtain valid results, namely for users who are above the age of 21 years.

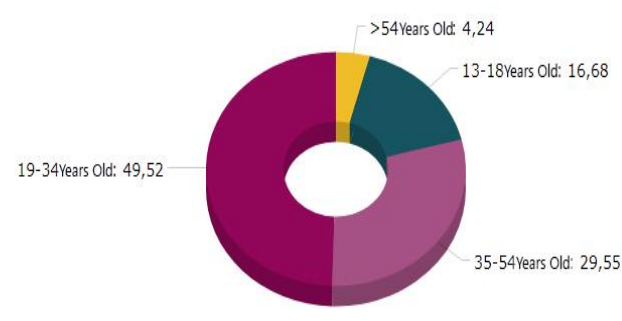

Denomination : \%

Fig. 3. Internet Users by Age Group (2017).

The technique of determining sample size uses the Slovin Technique [15] for a sample whose population is known, can be calculated using the formula:

$n=\frac{N}{1+N e^{2}}$

Where:

$\mathrm{n}=$ sample

$\mathrm{N}=$ Total Population

$\mathrm{e}=$ Estimated error rate

The number of users based on data obtained over 19 years of age is as follows, 73,642,352 + 42,333,330+6,074,224 $=122,049,906$ Internet Users.

Then:

$$
\begin{gathered}
n=\frac{122,049,906}{1+122,049,906(0.06)^{2}}=277.7771456 \\
\approx 278 \text { Sample }
\end{gathered}
$$

The sample criteria taken are e-commerce users who are over 21 years old starting in 2018. Following Circular No. 14/17 / DASP concerning Amendment to Circular No. 11/10 / DASP concerning the Implementation of Card-Based Payment Instrument Activities (APMK) issued by Bank Indonesia, that the minimum age for credit card ownership is 21 years old.[16] 


\section{Research Model}

The study was conducted using a modified DeLone and McLean model that Tella developed in his research entitled Determinants of E-Payment Systems Success: A User's Satisfaction Perspective [4]. Where the results of the research determine the factors determined on User Satisfaction. The research model used is as follows:

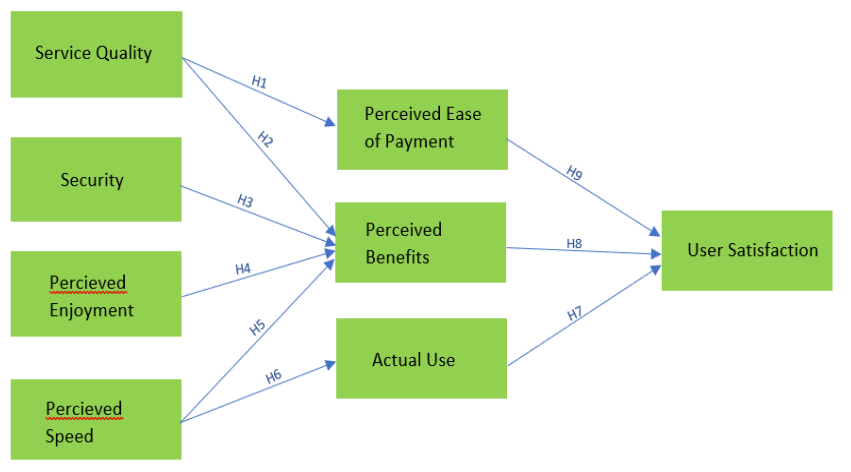

Fig. 4. Research Model.

Different from previous research, this research is testing the factors in the research model to find out what factors are significant to the e-commerce Customer Satisfaction in Indonesia on the payment system methods that have been applied in Indonesia. Where research conducted using variables by the research model, but each variable that has been determined in the research model has questions from different sources of reference from previous research.

\section{Research Hypothesis}

Based on the modification model of DeLone and McLean [4], the dependent variable in this study is customer satisfaction while the independent variable is service quality [17], ease of payment, speed and enjoyment/pleasure obtained, security, real use, and perceived benefits. In this research the hypothesis proposed by the researcher is as follows:

H1: Service quality on the payment system method applied by e-Commerce in Indonesia significantly determines the Perceived Ease of Payment perception.

H2: The quality of service on the payment system method that has been implemented by e-Commerce in Indonesia significantly determines the Perceived Benefits.

H3: Transaction security The payment system method that has been implemented by e-commerce in Indonesia significantly determines the benefits received.

H4: Perceived Enjoyment in making transactions using the Payment System Method applied by e-commerce in Indonesia does significant mean the Perceived Benefits.

H5: The perceived speed in the payment system method that has been implemented by e-commerce in Indonesia is felt to significantly determine the Perceived Benefits.

H6: The perceived speed in the payment system method that has been implemented by e-commerce in Indonesia is felt to significantly determine the Active Use.
H7: Actual Use in the payment system method that has been implemented by e-commerce in Indonesia is felt to significantly determine Customer Satisfaction.

H8: The benefits received in the payment system methods that have been implemented by e-commerce in Indonesia are felt to significantly determine Customer Satisfaction.

H9: The ease of payment received in the payment system method that has been implemented by e-commerce in Indonesia is felt to significantly determine Customer Satisfaction.

\section{DATA ANALYSIS}

From the results of the distribution of respondents' demographic questionnaire in this study explained the number of respondents based on age, gender, occupation, payment system methods used, frequency of use in one week by respondents. The number of questionnaires was 425 collected and had met the criteria for the minimum number of samples and the tools used to analyze the results of this questionnaire were IBM SPSS AMOS V.26 software.

\section{A. Data Distribution of Respondents by Age}

Based on the questionnaire that was collected, the data obtained from the respondents included age divided into four, namely the age of 17-24 years, 25-34 years, 35-49 years and 50 years and above. First, the group of respondents aged 17-24 years was 138 respondents (32\%). Second, the group of respondents aged 25-34 years was 180 respondents (42\%). Third, the group of respondents aged 35-49 years was 79 respondents $(19 \%)$. Fourth, groups of respondents aged 50 years and over were 28 respondents (7\%). The results of respondents based on age can be seen in Fig. 4. Judging by age level, it can be concluded that customers who transact on eCommerce in Indonesia vary but are dominant at the age of 2534 years.

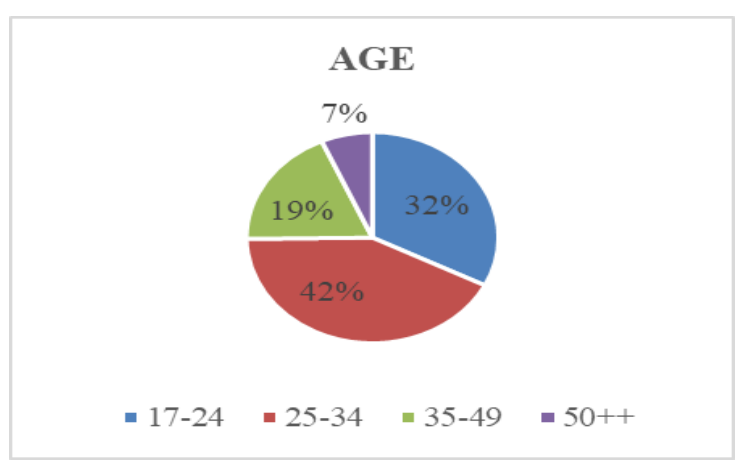

Fig. 5. Respondent Diagram based on Age.

\section{B. Respondent Data Distribution by Gender}

Through the questionnaire distributed, data were obtained based on the sex of the respondent. Fig. 5 shows the results of 425 respondents by sex, where the results of the responder sharing between Men and Women with male responders as many as 165 people $(39 \%)$ and the remaining 260 people $(61 \%)$ are users with the sex of Women. Based on the results of these respondents it can be concluded that e-commerce customers in Indonesia both male and female sex, so it does not require users with certain gender criteria in their use. 


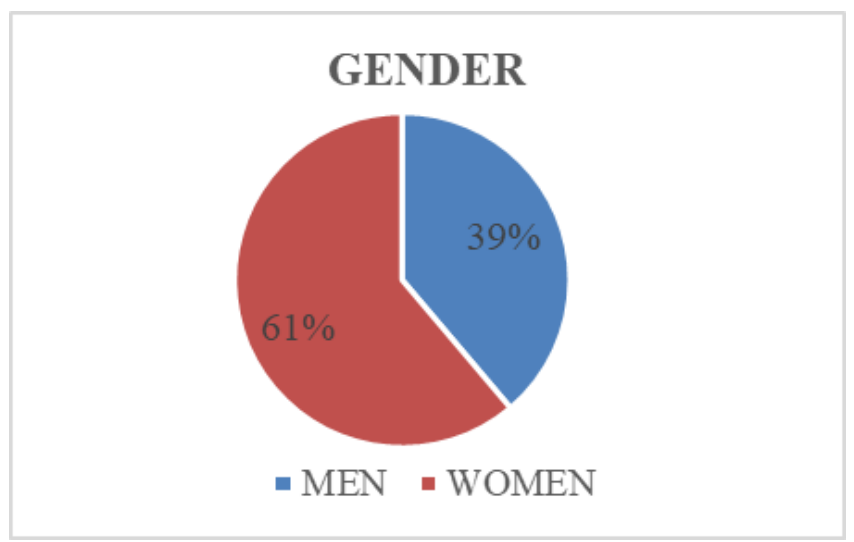

Fig. 6. Respondent Diagram based on Gender.

\section{Data of Respondents Distribution based on Payment System Methods}

Through a questionnaire distributed the respondents' data obtained based on the Payment System Method most often used in accordance with Fig. 7. Based on the 425 respondents' answers in Fig. 6, it is known that the percentage of Payment System Method information that is most often used in making payment transactions in e-commerce in Indonesia is Online Credit Card (27\%), followed by payment through Digital Wallet (24\%) which is slightly different from Virtual Account (23\%) payment which is the same as Online Bank Transfer (23\%) and is the last method with the Cash On Delivery system (3\%).

\section{PAYMENT SYSTEM METHOD}

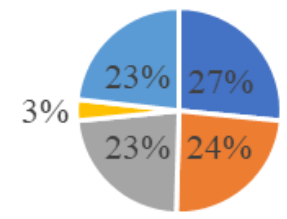

\section{- Credit Card Online \\ - Electronic Wallet \\ - Transfer Bank Online \\ - Cash On Delivery (COD) \\ - Virtual Account}

Fig. 7. Respondent Diagram based on Payment System Method.

\section{Validity Test}

In research using a questionnaire, a validity test is needed to ensure that the questionnaire instruments distributed are valid and determine the quality of research data. A valid instrument means that the instrument can be used to measure what should be measured [18]. Test the validity of the data obtained from the preliminary questionnaire tabulation results. Testing the validity of the preliminary questionnaire was carried out using IBM AMOS V.26 software. Validity testing can be seen from the loading factor value. Based on AMOS output, this value can be seen in the path diagram or AMOS output on Estimates à scalars à standardized regression weights. An indicator is valid if the Estimate is greater than 0.5 . The following table contains the results of the calculation of the validity test of each research variable.

TABLE I. VALIDITY TEST

\begin{tabular}{|l|l|l|}
\hline Question & Variable & Estimate \\
\hline AC1 & AC & 0.571 \\
\hline AC2 & AC & 0.604 \\
\hline AC3 & AC & 1.027 \\
\hline PB1 & PB & 0.815 \\
\hline PB2 & PB & 0.638 \\
\hline PB3 & PB & 0.544 \\
\hline PE1 & PE & 0.648 \\
\hline PE2 & PE & 0.568 \\
\hline PP1 & PP & 0.533 \\
\hline PP2 & PP & 0.559 \\
\hline PP3 & PP & 0.742 \\
\hline PS1 & PS & 0.67 \\
\hline PS2 & PS & 0.614 \\
\hline PS3 & PS & 0.506 \\
\hline SC1 & SC & 0.727 \\
\hline SC2 & SC & 0.704 \\
\hline SC3 & SC & 0.637 \\
\hline SQ1 & SQ & 0.582 \\
\hline SQ2 & SQ & 0.532 \\
\hline SQ3 & SQ & 0.868 \\
\hline US1 13512 \\
\hline US2 & US & 0.514 \\
\hline US3 & & 0.502 \\
\hline & US & \\
\hline
\end{tabular}

Based on the results of the management of Amos as shown in the Table I that there is no Estimate of all indicators smaller than 0.50. Thus, all indicators are declared valid and the model evaluation process can be continued.

\section{E. ReliabilityTest}

By conducting a reliability test it is measured using the Cronbach's Alpha value. Cronbach's Alpha reliability levels of more than 0.6 are stated as the minimum acceptance threshold [19]. On this basis, the authors chose the Cronbach's Alpha degree used in this study to [20] be greater or equal to the value 0.6 . Table II presents the results of the reliability test calculation. AMOS does not issue this value so it needs its calculation. Calculation of CR values can be seen in Table IV. The following reliability can be measured by calculating the CR and VE values on the results issued by the SPSS AMOS application as follows: 
TABLE II. RATIO CRITICAL ASESSMENT

\begin{tabular}{|l|l|l|}
\hline Construct & CR & Explanation \\
\hline Service quality & 0.617 & Acceptable \\
\hline Perceived ease of payment & 0.914 & Good \\
\hline Perceived speed & 0.669 & Acceptable \\
\hline Perceived enjoyment & 0.914 & Good \\
\hline Security & 0.616 & Acceptable \\
\hline Actual use & 0.735 & Good \\
\hline Perceived benefits & 0.801 & Good \\
\hline User satisfaction & 0.776 & Good \\
\hline
\end{tabular}

Based on the results of these calculations, because there is no construct reliability value whose value is below 0.60 , all constructs in this study deserve to be used in the research model.

\section{F. Structural Equation Modeling (SEM)}

In this study, there are 8 exogenous variables, namely Service quality (SQ), Perceived Ease of payment (PP), Security (SC), Perceived enjoyment (PE), Perceived speed (PS), Actual use (AC), Perceived benefits (PB), and User satisfaction (US). These variables are each connected with endogenous variables. This model was evaluated using the IBM SPSS AMOS V.26 application, with parameters namely Chi-square, p-value, RMSEA, GFI, AGFI, CMIN / DF, TLI, and CFI, to determine whether there is a substantive effect of the influence of the independent latent variable on the latent variable dependent. The Fig. 8 shows the path diagram of the model run on the IBM SPSS AMOS V.26 program.

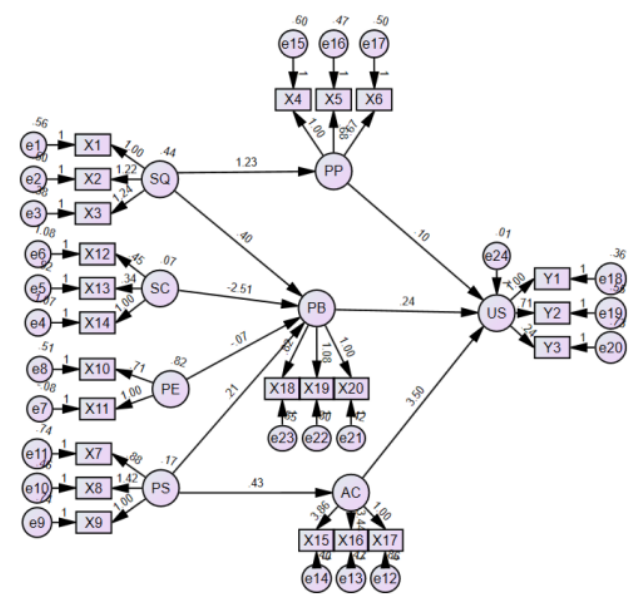

Fig. 8. Path Diagram after Application is run.

\section{G. Evaluation of the Goodness of Fit Criteria Index Model}

Evaluation of the Index Model Goodness of Fit Criteria is performed to see the Index that illustrates the overall suitability of the model calculated from the squared residuals of the predicted model compared to the actual data released at the time of using IBM SPSS AMOS V.26. The results of SEM model calculations as shown in the research model produce goodness of fit index as shown in Table III.
TABLE III. INDEX GOODNESS OF FIT

\begin{tabular}{|l|l|l|l|}
\hline Criteria & Results & Critical Value & Conclusions \\
\hline Chi-square & 5,028 & $\geq 0,05$ & Very Good \\
\hline p-value & 0,529 & $\geq 0,05$ & Good \\
\hline RMSEA & 0,050 & $\leq 0,08$ & Good \\
\hline GFI & 0,934 & $\geq 0,90$ & Good \\
\hline AGFI & 0,920 & $\geq 0,90$ & Very Good \\
\hline CFI & 0,974 & $\geq 0,95$ & Good \\
\hline
\end{tabular}

The value displayed on Table III have criteria is quite good in managing research data, due to the results issued when the program is run Chi-square value is greater> 0.05 The significance level used in the study is $\pm 95 \%$, while for the $p$ value is $>0.05$ so it has a chance to receive $\mathrm{H} 0$. While the RMSEA value is said to be a Good Fit value because it is still in a position $<0.08$. GFI values $>0.90$ indicate the model being tested has a good fit. AGFI is 0.934 where the number is close to 1 so it can be said that the tests have been done well. And for the CFI value obtained in the study was very good at 0.974 where this value approaches the number 1 which can be said Good Fit.

\section{H. Analysis of Direct Effects, Indirect Effects and Total Effects}

In this research, structural equation modeling analysis is also used as a tool that describes the relationship between the variables in this research model. In general, effects or effects can be divided into direct effects, indirect effects, and total effects.

The direct effect between the two latent variables occurs when there is an arrow connecting the two variables, where this effect is measured by the estimated value between the variables. Indirect effects (indirect effects) between the two variables can occur when a variable affects other variables through one or more latent variables following the path contained in the research model. While the overall effect (total effects) between the two latent variables is the sum of the direct effects and all indirect effects contained in the research model. The direct effect of this research model is presented in the Table IV.

The measurement results show that the variable that has the greatest direct effect on customer satisfaction is the Perceived Enjoyment variable, which is 1.051. From these measurements, the variable that has the greatest indirect effect on customer satisfaction is the Perceived Ease of Payment variable, which is equal to 0,130 .

The indirect effect (indirect effect) means the effect of an exogenous variable on the endogenous variable through endogenous intervening variables. While the total effect (total effect) is the result of the sum of direct and indirect effects. Based on the results of the analysis carried out with the IBM SPSS AMOS program, the magnitude of the Indirect Effect and Total Effect in this study is shown in the Table V. 
TABLE IV. STANDARD DiRECT EFFECT - EstimATES

\begin{tabular}{|l|llllllll|}
\hline & PS & PE & SC & SQ & PB & PP & AC & US \\
\hline PB & .081 & -.094 & -.153 & .344 & .000 & .000 & .000 & .000 \\
PP & .000 & .000 & .000 & 1.000 & .000 & .000 & .000 & .000 \\
AC & 1.000 & .000 & .000 & .000 & .000 & .000 & .000 & .000 \\
US & .000 & .000 & .000 & .000 & .252 & .130 & .915 & .000 \\
$\mathbf{X 1 8}$ & .000 & .000 & .000 & .000 & .608 & .000 & .000 & .000 \\
$\mathbf{X 1 9}$ & .000 & .000 & .000 & .000 & .817 & .000 & .000 & .000 \\
$\mathbf{X 2 0}$ & .000 & .000 & .000 & .000 & .723 & .000 & .000 & .000 \\
Y3 & .000 & .000 & .000 & .000 & .000 & .000 & .000 & .182 \\
Y2 & .000 & .000 & .000 & .000 & .000 & .000 & .000 & .533 \\
Y1 & .000 & .000 & .000 & .000 & .000 & .000 & .000 & .744 \\
$\mathbf{X 6}$ & .000 & .000 & .000 & .000 & .000 & .612 & .000 & .000 \\
$\mathbf{X 5}$ & .000 & .000 & .000 & .000 & .000 & .629 & .000 & .000 \\
$\mathbf{X 4}$ & .000 & .000 & .000 & .000 & .000 & .729 & .000 & .000 \\
$\mathbf{X 1 5}$ & .000 & .000 & .000 & .000 & .000 & .000 & .731 & .000 \\
$\mathbf{X 1 6}$ & .000 & .000 & .000 & .000 & .000 & .000 & .657 & .000 \\
$\mathbf{X 1 7}$ & .000 & .000 & .000 & .000 & .000 & .000 & .181 & .000 \\
$\mathbf{X 7}$ & .382 & .000 & .000 & .000 & .000 & .000 & .000 & .000 \\
$\mathbf{X 8}$ & .648 & .000 & .000 & .000 & .000 & .000 & .000 & .000 \\
$\mathbf{X 9}$ & .430 & .000 & .000 & .000 & .000 & .000 & .000 & .000 \\
$\mathbf{X 1 0}$ & .000 & .669 & .000 & .000 & .000 & .000 & .000 & .000 \\
$\mathbf{X 1 1}$ & .000 & 1.051 & .000 & .000 & .000 & .000 & .000 & .000 \\
$\mathbf{X 1 2}$ & .000 & .000 & .563 & .000 & .000 & .000 & .000 & .000 \\
$\mathbf{X 1 3}$ & .000 & .000 & .586 & .000 & .000 & .000 & .000 & .000 \\
$\mathbf{X 1 4}$ & .000 & .000 & .561 & .000 & .000 & .000 & .000 & .000 \\
$\mathbf{X 3}$ & .000 & .000 & .000 & .803 & .000 & .000 & .000 & .000 \\
$\mathbf{X 2}$ & .000 & .000 & .000 & .755 & .000 & .000 & .000 & .000 \\
$\mathbf{X 1}$ & .000 & .000 & .000 & .663 & .000 & .000 & .000 & .000 \\
\hline
\end{tabular}

TABLE V. STANDARD INDIRECT EFFECT - ESTIMATES

\begin{tabular}{|l|llllllll|}
\hline & PS & PE & SC & SQ & PB & PP & AC & US \\
\hline PB & .000 & .000 & .000 & .000 & .000 & .000 & .000 & .000 \\
PP & .000 & .000 & .000 & .000 & .000 & .000 & .000 & .000 \\
AC & .000 & .000 & .000 & .000 & .000 & .000 & .000 & .000 \\
US & .937 & -.023 & -.232 & .223 & .000 & .000 & .000 & .000 \\
X18 & .073 & -.055 & -.559 & .235 & .000 & .000 & .000 & .000 \\
$\mathbf{X 1 9}$ & .097 & -.072 & -.739 & .310 & .000 & .000 & .000 & .000 \\
$\mathbf{X 2 0}$ & .088 & -.065 & -.671 & .282 & .000 & .000 & .000 & .000 \\
Y3 & .172 & -.004 & -.043 & .041 & .047 & .023 & .167 & .000 \\
Y2 & .504 & -.012 & -.124 & .120 & .137 & .068 & .487 & .000 \\
Y1 & .700 & -.017 & -.173 & .167 & .190 & .094 & .677 & .000 \\
$\mathbf{X 6}$ & .000 & .000 & .000 & .612 & .000 & .000 & .000 & .000 \\
$\mathbf{X 5}$ & .000 & .000 & .000 & .631 & .000 & .000 & .000 & .000 \\
$\mathbf{X 4}$ & .000 & .000 & .000 & .727 & .000 & .000 & .000 & .000 \\
$\mathbf{X 1 5}$ & .731 & .000 & .000 & .000 & .000 & .000 & .000 & .000 \\
$\mathbf{X 1 6}$ & .656 & .000 & .000 & .000 & .000 & .000 & .000 & .000 \\
$\mathbf{X 1 7}$ & .185 & .000 & .000 & .000 & .000 & .000 & .000 & .000 \\
$\mathbf{X 7}$ & .000 & .000 & .000 & .000 & .000 & .000 & .000 & .000 \\
$\mathbf{X 8}$ & .000 & .000 & .000 & .000 & .000 & .000 & .000 & .000 \\
$\mathbf{X 9}$ & .000 & .000 & .000 & .000 & .000 & .000 & .000 & .000 \\
$\mathbf{X 1 0}$ & .000 & .000 & .000 & .000 & .000 & .000 & .000 & .000 \\
$\mathbf{X 1 1}$ & .000 & .000 & .000 & .000 & .000 & .000 & .000 & .000 \\
$\mathbf{X 1 2}$ & .000 & .000 & .000 & .000 & .000 & .000 & .000 & .000 \\
$\mathbf{X 1 3}$ & .000 & .000 & .000 & .000 & .000 & .000 & .000 & .000 \\
$\mathbf{X 1 4}$ & .000 & .000 & .000 & .000 & .000 & .000 & .000 & .000 \\
$\mathbf{X 3}$ & .000 & .000 & .000 & .000 & .000 & .000 & .000 & .000 \\
$\mathbf{X 2}$ & .000 & .000 & .000 & .000 & .000 & .000 & .000 & .000 \\
$\mathbf{X 1}$ & .000 & .000 & .000 & .000 & .000 & .000 & .000 & .000 \\
\hline & & & & & & & & \\
\end{tabular}

Because of the direct influence and indirect effect between variables in this research model, it is necessary to measure the total effect. The results of the measurement of the total effect between variables is shown in Table VI.

Based on the results on Table VI of these measurements it is known that the variable that has the greatest total effect on the customer satisfaction variable is the Actual Use (AC) variable, which is 3,863 .

TABLE VI. STANDARD TOTAL EFFECT - EsTIMATES

\begin{tabular}{|c|c|c|c|c|c|c|c|c|}
\hline & PS & PE & SC & SQ & PB & PP & AC & US \\
\hline PB & .205 & .069 & $\overline{2.507}$ & .404 & .000 & .000 & .000 & .000 \\
\hline $\mathbf{P P}$ & .000 & .000 & .000 & $\begin{array}{l}1.22 \\
9\end{array}$ & .000 & .000 & .000 & .000 \\
\hline $\mathrm{AC}$ & .427 & .000 & .000 & .000 & .000 & .000 & .000 & .000 \\
\hline US & $\begin{array}{l}1.54 \\
5\end{array}$ & $\begin{array}{l}- \\
.017\end{array}$ & -.610 & .225 & .243 & .103 & $\begin{array}{l}3.50 \\
1\end{array}$ & .000 \\
\hline $\begin{array}{l}\mathrm{X} 1 \\
8\end{array}$ & .168 & $\begin{array}{l}- \\
.057\end{array}$ & $\begin{array}{l}- \\
2.055\end{array}$ & .331 & .820 & .000 & .000 & .000 \\
\hline $\begin{array}{l}\mathrm{X} 1 \\
9\end{array}$ & .221 & $\begin{array}{l}- \\
.075\end{array}$ & - & .435 & $\begin{array}{l}1.07 \\
8\end{array}$ & .000 & .000 & .000 \\
\hline $\begin{array}{l}\mathrm{X} 2 \\
\mathbf{0}\end{array}$ & .205 & $\begin{array}{l}- \\
.069\end{array}$ & $\overline{2.507}$ & .404 & $\begin{array}{l}1.00 \\
0\end{array}$ & .000 & .000 & .000 \\
\hline Y3 & .367 & $\begin{array}{l}- \\
.004\end{array}$ & -.145 & .053 & .058 & .025 & .831 & .237 \\
\hline Y2 & $\begin{array}{l}1.09 \\
0\end{array}$ & $\begin{array}{l}- \\
.012\end{array}$ & -.430 & .159 & .171 & .073 & $\begin{array}{l}2.47 \\
0\end{array}$ & .705 \\
\hline Y1 & $\begin{array}{l}1.54 \\
5\end{array}$ & $\begin{array}{l}- \\
.017\end{array}$ & -.610 & .225 & .243 & .103 & $\begin{array}{l}3.50 \\
1\end{array}$ & $\begin{array}{l}1.00 \\
0\end{array}$ \\
\hline X6 & .000 & .000 & .000 & .818 & .000 & .666 & .000 & .000 \\
\hline X5 & .000 & .000 & .000 & .834 & .000 & .679 & .000 & .000 \\
\hline $\mathrm{X} 4$ & .000 & .000 & .000 & $\begin{array}{l}1.22 \\
9\end{array}$ & .000 & $\begin{array}{l}1.00 \\
0\end{array}$ & .000 & .000 \\
\hline $\begin{array}{l}\mathrm{X} 1 \\
5\end{array}$ & $\begin{array}{l}1.65 \\
0\end{array}$ & .000 & .000 & .000 & .000 & .000 & $\begin{array}{l}3.86 \\
3\end{array}$ & .000 \\
\hline $\begin{array}{l}\mathrm{X} 1 \\
6\end{array}$ & $\begin{array}{l}1.46 \\
8\end{array}$ & .000 & .000 & .000 & .000 & .000 & $\begin{array}{l}3.43 \\
6\end{array}$ & .000 \\
\hline $\begin{array}{l}\mathrm{X} 1 \\
7\end{array}$ & .427 & .000 & .000 & .000 & .000 & .000 & $\begin{array}{l}1.00 \\
0\end{array}$ & .000 \\
\hline $\mathrm{X} 7$ & .883 & .000 & .000 & .000 & .000 & .000 & .000 & .000 \\
\hline $\mathrm{X8}$ & $\begin{array}{l}1.42 \\
3\end{array}$ & .000 & .000 & .000 & .000 & .000 & .000 & .000 \\
\hline X9 & $\begin{array}{l}1.00 \\
0\end{array}$ & .000 & .000 & .000 & .000 & .000 & .000 & .000 \\
\hline $\begin{array}{l}\mathrm{X} 1 \\
\mathbf{0}\end{array}$ & .000 & .707 & .000 & .000 & .000 & .000 & .000 & .000 \\
\hline $\begin{array}{l}\mathrm{X} 1 \\
1\end{array}$ & .000 & $\begin{array}{l}1.00 \\
0\end{array}$ & .000 & .000 & .000 & .000 & .000 & .000 \\
\hline $\begin{array}{l}\mathrm{X} 1 \\
2\end{array}$ & .000 & .000 & .447 & .000 & .000 & .000 & .000 & .000 \\
\hline $\begin{array}{l}\mathrm{X} 1 \\
3\end{array}$ & .000 & .000 & .343 & .000 & .000 & .000 & .000 & .000 \\
\hline $\begin{array}{l}X 1 \\
4\end{array}$ & .000 & .000 & 1.000 & .000 & .000 & .000 & .000 & .000 \\
\hline $\mathrm{X3}$ & .000 & .000 & .000 & $\begin{array}{l}1.24 \\
2\end{array}$ & .000 & .000 & .000 & .000 \\
\hline $\mathrm{X} 2$ & .000 & .000 & .000 & $\begin{array}{l}1.22 \\
3\end{array}$ & .000 & .000 & .000 & .000 \\
\hline $\mathrm{X} 1$ & .000 & .000 & .000 & $\begin{array}{l}1.00 \\
0\end{array}$ & .000 & .000 & .000 & .000 \\
\hline
\end{tabular}




\section{Hypothesis Testing}

The results of the Structural Equation Modeling (SEM) analysis using the IBM SPSS AMOS V26 application produced is shown in the Table VII.

TABLE VII. HYPOTHESIS TEST

\begin{tabular}{|c|c|c|c|c|c|c|c|}
\hline & & & Estimate & S.E. & C.R. & $\mathbf{P}$ & Label \\
\hline$\overline{\mathrm{PP}}$ & <--- & $\overline{S Q}$ & 1.229 & .097 & 12.712 & *** & Significant \\
\hline PB & $<--$ & SQ & .404 & .065 & 6.250 & $* * *$ & Significant \\
\hline PB & $<--$ & SC & -2.507 & .593 & -4.229 & $* * *$ & Significant \\
\hline PB & $<--$ & PE & -.069 & .058 & -1.184 & .237 & Not significant \\
\hline PB & $<--$ & PS & 205 & .102 & 2.013 & .044 & Significant \\
\hline $\mathrm{AC}$ & $<--$ & PS & .427 & .132 & 3.238 & .001 & Significant \\
\hline US & $<--$ & PP & .103 & .044 & 2.337 & .019 & Significant \\
\hline US & $<--$ & PB & .243 & .057 & 4.264 & $* * *$ & Significant \\
\hline US & $<--$ & AC & 3.501 & 1.025 & 3.416 & $* * *$ & Significant \\
\hline
\end{tabular}

H1. Based on Table VII summarizing the results of the structural model evaluation, it can be seen the value of Tstatistics from Service quality to the benefits received is PValues $<0.05$ or equal to $* * *$ so it can be concluded that $\mathrm{H} 1$ is received / significant, Service quality has a positive effect on Perceived Ease of Payment on the Payment System Method that has been applied by e-commerce in Indonesia. This shows that the Payment System Method that has been applied by ecommerce in Indonesia can be accepted as a service that is useful for daily activities, a service that provides transaction convenience that makes it easy for e-commerce customers to make transactions.

H2. Based on Table VII summarizing the results of the structural model evaluation, it can be seen the value of Tstatistics from Service quality to the benefits received is PValues $<0.05$ or equal to $* * *$ so it can be concluded that $\mathrm{H} 1$ is received / significant, Service quality has a positive effect on the Perceived Benefits of the Payment System Method that has been applied by e-commerce in Indonesia.

This shows that the Payment System Method that has been applied by e-commerce in Indonesia can be accepted as a service that is useful for daily activities, services that provide benefits received by customers in using the Payment System Method that has been applied by e-commerce in Indonesia.

H3. From Table VII, it can be seen that the relation of the transaction security variable to the benefits received gives a PValues value $<0.05$ or equal to $* * *$. This value indicates that transaction security has a significant effect on the benefits received Payment System Method that has been applied by ecommerce in Indonesia. This shows that the Payment System Method that has been implemented by e-commerce in Indonesia can be accepted as a safe and beneficial service from the customer side in the use of Payment System Method transactions that have been implemented by e-commerce in Indonesia.

H4. Based on the results of statistical tests in this study, the perceived comfort variable has a non-significance value/pvalue of 0.237 where the significance value is greater than 0.05 , then the $\mathrm{H} 4$ hypothesis is not accepted which means the perceived comfort variable does not have a significant effect on the benefits received on the Payment System Method implemented by e-commerce in Indonesia.

H5. From Table VII, it can be seen that the relation of the Perceived Speed variable to the Perceived Benefits gives a PValues value of 0.044 (P-Values> 0.05). This value indicates that the perceived speed has a significant effect on the benefits received on the Payment System Method implemented by ecommerce in Indonesia.

H6. Based on the Table VII, it is known that the relationship between Perceived Speed and Active Use has a PValue (P-Values <0.05) with a value of 0.001. Because of this, H6 was accepted and pointed out that Perceived Speed has a significant effect on the Actual use of the payment system method that has been implemented by e-commerce in Indonesia.

H7. From the Table VII, it can be seen that the relation of the Active Use variable to Customer Satisfaction gives a PValues value $<0.05$ or equal to $* * *$. This value indicates that Active Use has a significant effect on Customer Satisfaction for customers who transact using the Payment System Method that has been implemented e-commerce in Indonesia. This shows that the Payment System Method that has been applied by e-commerce in Indonesia has provided satisfaction for active customers transacting in Indonesia.

H8. From the Table VII, it can be seen that the relation of Perceived Benefits to Perceived Benefits gives a P-Value value $<0.05$ or equal to $* * *$. This value indicates that Active Use has a significant effect on Customer Satisfaction for customers who transact using the Payment System Method that has been implemented e-commerce in Indonesia. This shows that the Payment System Method that has been applied by e-commerce in Indonesia provides benefits for e-commerce customers who make transactions and affect customer satisfaction.

H9. Based on the statistical test results in this study in the Table VII, the Perceived Ease of Payment variable has a significance value/p-value of 0.019 where the significance value is greater than 0.05 , then the $\mathrm{H} 9$ hypothesis is accepted which means the perceived Speed variable has a significant effect on Customer Satisfaction on the Payment System Method implemented by e-commerce in Indonesia. This shows that the Payment System Method that has been applied by ecommerce in Indonesia provides a perceived Speed for ecommerce customers who make transactions and affects the Customer Satisfaction.

\section{RESUlTS AND DisCUSSION}

The results of the study carried out explained that customer satisfaction has a significant effect on the factors of Service Quality, Benefits Received, Transaction Security, Speed, Active Use, Received Benefits, and ease of transactions with PValues $<0.05$ as shown in Table VII. While one factor that has no significant effect, where the value of P-Values $<0.05$ or 0.237 is the factor of the benefits received by customers. This research was conducted with 425 respondents with criteria determined by the researcher. The need for the development and improvement of the Payment System Method for all significant or insignificant factors to improve or develop the 
payment system method which is currently being applied to ecommerce in Indonesia.

\section{CONCLUSION AND RECOMMENDATION}

\section{A. Consulation}

This study shows that there are significant or insignificant factors of customer satisfaction with the Payment System Method that has been applied by e-commerce in Indonesia. Factors or variables studied, determine e-commerce customer satisfaction with the Payment System Method that has been applied to e-commerce in Indonesia. Based on the results of the analysis and hypothesis testing that has been done by researchers, the following conclusions can be drawn,

1) The results show that Service Quality has a significant effect on the Ease of Payment Perceived in the Payment System Method which has been implemented by e-commerce in Indonesia. By accepting this hypothesis, it can be interpreted that Service Quality and Ease of Payment Perception affect the ease of payment.

2) The results show that the quality of service in the payment system method applied by e-Commerce in Indonesia significantly determined the Perceived Benefits. This hypothesis proves that the quality of service in the Payment System Method can increase the intention of e-commerce customers in Indonesia.

3) The results show that the transaction security of the payment system method that has been applied by e-commerce in Indonesia has a significant influence in determining the benefits received. This proves that the security factor in the Payment Method that has been applied has a significant effect on the benefits received which also affects Customer Satisfaction.

4) The results showed that the Perceived Enjoyment in the payment system method that has been implemented by ecommerce in Indonesia does not significantly determine the Perceived Benefit. This proves that the speed of the process or service that is owned by the Payment System Method currently applied by e-commerce in Indonesia has no significant effect on the perceived benefits.

5) The results show that the perceived speed had a significant effect on the perceived benefits. This proves that the speed of a good Payment System Method makes customers feel the benefits that have an effect on customer satisfaction in the implementation of the Payment System Method by ecommerce in Indonesia.

6) The results show that Speed Perceived significantly determines Actual usage which proves that the Speed of the Payment System Method can both make customers active users of the Payment System Method that has been implemented by e-commerce in Indonesia.

7) The results showed that Active Use as a significant influence in determining Customer Satisfaction which proves that active users influence Customer Satisfaction.

8) The results showed that the benefits received significantly influence customer satisfaction which proves that the benefits received by customers using the Payment System Method that has been implemented by e-commerce in Indonesia affect Customer Satisfaction.

9) The results showed that the ease of payment received had a significant influence in determining Customer Satisfaction so that the ease of payment received had a very significant influence on Customer Satisfaction.

\section{B. Recommendation}

Based on the results of the study, the Payment System Method in particular that has been applied to e-commerce companies in Indonesia can be redeveloped to increase customer satisfaction with payment method services that have been implemented in Indonesia. Some suggestions that can be given are as follows:

a) Because the benefits received have a significant effect on Customer Satisfaction, Recommends that the payment system method can be improved through the Service Quality given so that it can provide more benefits for e-commerce customers in conducting transactions.

b) The benefits received have a significant effect on Customer Satisfaction, so what needs to be improved in the Payment System Method that has been implemented in Indonesia are Service Quality, Security, and Perceived Speed. While for perceived comfort must still be considered even though the research conducted that for Perceived Enjoyment is not significant.

c) Actual Use has a significant effect on Customer Satisfaction. Thus, a target marketing strategy is needed for active use that can be done through digital and non-digital media to conduct transactions with the Payment System Method that has been applied.

The next suggestion that can be given for future research is to consider the aspects of risk in the research to be carried out and to redevelop the research model to get a general model that can explain the factors that influence customer satisfaction with the Payment System Method, especially those that have been applied to companies' e-commerce in Indonesia. The research can be continued using the development of this research model with variables that are more relevant to the development of Payment System Methods that have been applied by ecommerce in Indonesia.

\section{REFERENCES}

[1] Databoks, "Transaksi E-Commerce Indonesia Naik 500\% dalam 5 Tahun,” Katadata, $2018 . \quad$ Available: https://databoks.katadata.co.id/datapublish/2016/11/16/transaksi-ecommerce-indonesia-naik-500-dalam-5-tahun [Accessed: 21-Sep-2019].

[2] W. Wresch and S. Fraser, "Persistent Barriers to E-commerce in Developing Countries," J. Glob. Inf. Manag., vol. 19, no. 3, pp. 30-44, 2011.

[3] A. Mukherjee and P. Nath, Role of electronic trust in online retailing: A re-examination of the commitment-trust theory, vol. 41, no. 9-10. 2007.

[4] A. Tella, "Determinants of E-Payment Systems Success: A User's Satisfaction Perspective," Int. J. E-Adoption, vol. 4, no. 3, pp. 15-38, 2012.

[5] L. Chen, R. Nath, and L. Chen, "Determinants of Mobile Payments : An Empirical Analysis Determinants of Mobile Payments: An Empirical Analysis," vol. 17, no. 1, 2008. 
[6] O. Ganiyu and A. Polytechnic, "Customers satisfaction and electronic payment systems in the nigerian banking sector," vol. 3, no. 1, pp. 2336.

[7] Turban, Electronic Commerce: A Managerial and Social Networks Perspective, 8th Edition. Springer, 2015.

[8] "Sistem Pembayaran - Bank Sentral Republik Indonesia," Bank Indonesia, 2011. [Online]. Available: https://www.bi.go.id/id/sistempembayaran/di-indonesia/Contents/Default.aspx. [Accessed: 21-Sep2019].

[9] R. Mangiaracina and G. Brugnoli, "The eCommerce Customer Journey: A Model to Assess and Compare the User Experience of the eCommerce Websites". Journal of Internet Banking and Commerce(JIBC). Vol.14 no.3, December 2009.

[10] B. Nitin, G. Asst, and P. Subharti, "The effect of electronic payment on customer satisfaction,” Int. J. Adv. Res. Innov. Ideas Educ., vol. 3, no. 3, pp. 3556-3579, 2017.

[11] T. Adeyinka, "Predicting Users ' Continuance Intention Toward Epayment System : An Extension of the Technology Acceptance Model," no. March 2014, pp. 46-67, 2015.

[12] X. W. Jichuan Wang, Structural Equation Modeling. WHILEY. ISBN: 978-1-119-97829-9. 2019.

[13] D. Astuti and F. N. Salisah, "Aanlisis Kualitas Layanan E-Commerce Terhadap Kepuasan Pelanggan Menggunakan Metode E-SERVQUAL ( Studi Kasus: Lejel Home Shopping Pekanbaru )," J. Rekayasa dan Manaj. Sist. Inf., vol. 2, no. 1, pp. 44-49, 2016.
[14] APJII, "Pengguna Internet di Indonesia 2018 Bertambah 28 Juta \& nbsp ;" 2018, 2019 .Available: https://apjii.or.id/content/read/104/348/BULETIN-APJII-EDISI-22--Maret-2018 [Accessed: 21-Sep-2019].

[15] J. H. W Abdillah, Partial Least Square (PLS): alternatif structural equation modeling (SEM) dalam penelitian bisnis. Yogyakarta: ANDI, 2015.

[16] Bank Indonesia, "SE Bank Indonesia -DASP," Bank Indonesia, 2009. [Online]. Available: https://www.bi.go.id/id/peraturan/sistempembayaran/Pages/pbi_184016.aspx. [Accessed: 21-Sep-2020].

[17] M. Sharma, S. K., \& Sharma, "Examining the role of trust and quality dimensions in the actual usage of mobile banking services: An empirical investigation.," Int. J. Inf. Manage., vol. 44, pp. 65-75, 2019.

[18] Sugiyono, "Metode Penelitian Kuantitatif Kualitatif dan R\&D," Metod. Penelit. Kuantitatif Kualitatif dan R\&D, vol. 53, no. 9, pp. 1689-1699, 2014.

[19] Y. Q. Mondiana, H. Pramoedyo, and E. Sumarminingsih, "Structural Equation Modeling on Likert Scale Data With Transformation by Successive Interval Method and With No Transformation," Int. J. Sci. Res. Publ., vol. 8, no. 5, pp. 398-405, 2018.

[20] E. Yani, A. F. Lestari, H. Amalia, and A. Puspita, "Pengaruh Internet Banking Terhadap Minat Nasabah Dalam Bertransaksi Dengan Technology Acceptance Model,” vol. 5, no. 1, pp. 34-42, 2018. 